\title{
20: 55274708-55178962
}

National Cancer Institute

\section{Source}

National Cancer Institute. 20:55274708-55178962. NCI Thesaurus. Code C41794.

Physical location of BMP7_Gene 